\title{
The Impact of "CYP2C9" and "VKORC1" Genetic Polymorphism upon Oral Anticoagulation Requirements
}

\author{
Hossam Yousef Kamal Mohammed, Yousry Zaki Al-zohairy, Mahmoud Abd El-latif Hashish \\ Clinical Pathology, Faculty of Medicine - Al Azhar University
}

\begin{abstract}
Background: Polymorphisms in the gene encoding the cytochrome P-450 2C9 enzyme (CYP2C9) are known to contribute to variability in sensitivity to Marevan. CYP2C9 is the enzyme primarily responsible for the metabolic clearance of s-enantiomer of Marevan. The VKORC1 is the target of Coumarin anticoagulants, and its common genetic variants result in altered sensitivity to Marevan. VKORC1 polymorphisms are associated with a need for lower doses of Marevan during long-term therapy.

Aim of work: This study aimed to assess the allelic frequencies and to investigate the relationship between "CYP2C9" and "VKORC1" genotype and vitamin K antagonist anticoagulation.

Subjects and Methods: This study was conducted on 40 patients. They were 24 females and 16 males with a male to female ratio 2:3. Their ages ranged from 28 to 72 years old. All the studied subjects were laboratory investigated with international normalized ratio (INR), complete blood count (CBC) and detection of vitamin K epoxide reductase complex 1 (VKORC1) and cytochrome P450 2C9 (CYP2C9) by polymerase chain reaction (P.C.R.) reverse hybridization method using PGX thrombo strip assay (Vienna Lab., Austria).

Results: Regarding the distribution of patients according to frequency of deep venous thrombosis (DVT) attacks, $16(40 \%)$ patients showed single attack of DVT and $24(60 \%)$ patients showed recurrent attacks. Patients with single attack of DVT were $12(75 \%)$ females and $4(25 \%)$ males with male to female ratio of 1:3. As for patients with recurrent attacks of DVT, they $13(54.2 \%)$ females and $11(45.8 \%)$ males with a male to female ratio of $1: 1.2$.

Conclusion: Detection of genetic polymorphisms in CYP2C9 and VKORC1 genes prior to onset of warfarin therapy, greatly influenced response to warfarin and shortened the time required to reach target INR, and hence reduced the risk of recurrence of deep venous thrombosis.
\end{abstract}

Keywords: CYP2C9, VKORC1, P.C.R, Warfarin (Marevan) oral anticoagulant.

\section{INTRODUCTION}

Oral anticoagulation with the vitamin $\mathrm{K}$ antagonist "Marevan" reduces the rate of thromboembolic events in patients with deep venous thrombosis "D.V.T." (1). However, Marevan is one of the most widely used anticoagulants, yet interindividual differences in drug response, a narrow therapeutic range and a high risk of bleeding or stroke complicate its use. To achieve and maintain an optimal Marevan dose, the prothrombin time and international normalized ratio "INR" are monitored, and doses are adjusted to maintain each patient's INR within a narrow therapeutic range. An INR of less than 2 is associated with an increased risk of thromboembolism ${ }^{(2)}$ and an INR of 4 or more is associated with an increased risk of bleeding ${ }^{(3)}$.

Received: 09/8/2018

Accepted: 19/8/2018
Polymorphisms in the gene encoding the cytochrome P-450 2C9 enzyme (CYP2C9) are known to contribute to variability in sensitivity to Marevan ${ }^{(4)}$.

CYP2C9 is the enzyme primarily responsible for the metabolic clearance of s-enantiomer of Marevan ${ }^{(5)}$.

Patients with certain common genetic variants of CYP2C9 require a lower dose of marevan and a longer time to reach a stable dose. They are also at higher risk for over- anticoagulation and serious bleeding ${ }^{(6)}$.

The vitamin K-dependent (VKD) blood coagulation proteins are components of the calcium-binding proteins family, which includes prothrombin, factors VII, IX, and $\mathrm{X}$, and proteins $\mathrm{C}, \mathrm{S}$ and $\mathrm{Z}$. These seven proteins have an essential role in the initiation and regulation of blood coagulation. Vitamin $\mathrm{K}$ epoxide 
reductase (VKORC1) recycles the vitamin $\mathrm{K}$ epoxide to the reduced form of vitamin $\mathrm{K}$, an essential co- factor in the formation of the active clotting factors II, VII, IX and X through $\gamma$ glutamyl carboxylation ${ }^{(5)}$.

The VKORC1 is the target of coumarin anticoagulants, and its common genetic variants result in altered sensitivity to Marevan. VKORC1 polymorphisms are associated with a need for lower doses of Marevan during longterm therapy ${ }^{(6)}$ and in some studies, were found to contribute to the variation in dose requirement more than CYP2C9 variants ${ }^{(7)}$.

On the basis of these observations, the Food and Drug Administration (FDA) approved a labeling change for Marevan that describes the reported

This study was conducted on 40 patients attending Nasr City Police Hospital Laboratory for follow up of their anticoagulation status. They were 24 females and 16 males with a male to female ratio $2: 3$. Their ages ranged from 28 to 72 years old.

\section{Inclusion criteria:}

Patients with deep venous thrombosis, stable continuous intake of oral anticoagulants and records of all the previous INR results since the start of treatment. Additionally, other inclusion criteria included the choice of resistant nonresponder patients at 2-3 $\mathrm{mg}$ dose of vitamin $\mathrm{K}$ antagonist oral anticoagulation, food (especially green vegetables rich in vitamin $\mathrm{K}$ ), concomitant medications that may affect the response of patients and history of recurrence of DVT.

\section{Exclusion criteria:}

\section{Statistical analysis:}

PASW statistical software package (V.18.0, IBM Corp., USA, 2010) was used for data analysis. Dates were expressed as Mean \pm SD for quantitative measures and both number and percentage for categorized data. Comparison between two independent mean groups for parametric data using Student $\mathrm{t}$ test. Chi-square effects of VKORC1 and CYP2C9 on dose requirements, the package insert as of August 2007 stated that "Lower initiation doses should be considered for patients with certain genetic Variations in CYP2C9 and VKORC1 enzymes". The FDA also approved chemical tests for these genetic variations ${ }^{(8)}$. However, there is little information about the relative contribution of VKORC1 and CYP2C9 to the anticoagulation response in patients during the initiation of Marevan therapy ${ }^{(\boldsymbol{9})}$.

The first months of anticoagulant treatment are particularly problematic, since the safe and effective dose for an individual patient is not known and is determined empirically ${ }^{(\mathbf{1 0})}$.

\section{SUBJECTS AND METHODS}

Patients who are less than 18 years old and patients with active malignancy.

Thorough history taking was made for all patients stressing on primary indication for oral anticoagulation, the INR achieved with a stable Marevan dose, the target INR, the use of concomitant medications (grouped according to those that increase and those that decrease the INR), details of diet intake and any history of bleeding or thrombosis with the medication.

For all the studied subjects, the following lab. Investigations were done: (1) INR and $\mathrm{CBC}$, (2) detection of CYP2C9 and VKORC1 by Polymerase Chain Reaction (P.C.R.) using PGX Thrombo Strip Assay, Vienna Lab., Austria, (3) Protein C, Protein S, Protein $\mathrm{Z}$ for studied subjects if needed.

test to study the association between each 2 variables or comparison between 2 independent groups as regards the categorized data. The probability of error at 0.05 was considered significant, while at 0.01 and 0.001 were highly significant. 
The Impact of "CYP2C9" and "VKORC1" Genetic Polymorphism upon Oral...

\section{RESULTS}

Table (1): Association between VKORC1 gene mutation and the studied parameters, age and gender

\begin{tabular}{|c|c|c|c|c|c|}
\hline Parameters & Wild type & Heterozygous & Homozygous & $\begin{array}{c}\text { Test of sig. and } P \\
\text { value }\end{array}$ & Sig. \\
\hline $\begin{array}{c}\text { Age } \\
\text { (years) }\end{array}$ & $49 \pm 13$ & $56 \pm 7.4$ & $57 \pm 18.49$ & $\begin{array}{c}\mathrm{x}^{2}=60.462 \\
\mathrm{P}=<0.001\end{array}$ & Sig. \\
\hline \multicolumn{6}{|c|}{ Gender } \\
\hline Female (s) & $\begin{array}{c}5 \\
(50 \%)\end{array}$ & $\begin{array}{c}19 \\
(73.1 \%)\end{array}$ & $\begin{array}{c}1 \\
(25 \%)\end{array}$ & \multirow{2}{*}{$\begin{array}{c}\mathrm{x}^{2}=3.381 \\
\mathrm{p}=0.184\end{array}$} & \multirow[b]{2}{*}{ Non-sig } \\
\hline $\operatorname{Male}(s)$ & $\begin{array}{c}5 \\
(50 \%)\end{array}$ & $\begin{array}{c}7 \\
(26.9 \%)\end{array}$ & $\begin{array}{c}3 \\
(75 \%)\end{array}$ & & \\
\hline
\end{tabular}

Table (2): Association between CYP2C9 $(430 \mathrm{C}>\mathrm{T})$ gene mutations and the studied parameters, age and gender

\begin{tabular}{|c|c|c|c|c|}
\hline Parameters & $\begin{array}{c}\text { Wild type CYP2C9 } \\
(430 \mathrm{C}>\mathrm{T})\end{array}$ & $\begin{array}{c}\text { Heterozygous } \\
\text { CYP2C }(430 \mathrm{C}>\mathrm{T})\end{array}$ & Test of sig. and $P$ & Significance \\
\hline $\begin{array}{c}\text { Age } \\
\text { (years) } \\
\text { mean } \pm \text { SD }\end{array}$ & $55.08 \pm 10.3$ & $48.16 \pm 10.3$ & $\begin{array}{c}x^{2}=30.196 \\
p=0.007\end{array}$ & Sig. \\
\hline \multicolumn{5}{|c|}{ Gender } \\
\hline $\begin{array}{l}\text { Female(s) } \\
\text { (\% of pts.) }\end{array}$ & $\begin{array}{c}19 \\
(55.88 \%)\end{array}$ & $\begin{array}{c}5 \\
(83.333 \%)\end{array}$ & \multirow{2}{*}{$\begin{array}{l}x^{2}=1.601 \\
p=0.206\end{array}$} & \multirow{2}{*}{ Non-sig. } \\
\hline \begin{tabular}{|c|} 
Male(s) \\
(\% of pts.)
\end{tabular} & $\begin{array}{c}15 \\
(44.1 \%)\end{array}$ & $\begin{array}{c}1 \\
(16.667 \%)\end{array}$ & & \\
\hline
\end{tabular}

Table (3): Association between VKORC1 (1639 G>A) gene mutation and frequency of recurrence

\begin{tabular}{|c|c|c|c|c|c|}
\hline \multicolumn{6}{|c|}{ VKORC1 (1639 G>A) } \\
\hline Parameters & Wild type & Heterozygous & Homozygous & Test of sig. and P value & Sig. \\
\hline $\begin{array}{l}\text { Single } \\
\text { attack }\end{array}$ & $\begin{array}{c}3 \\
(21.43 \%)\end{array}$ & $\begin{array}{c}11 \\
(78.57 \%)\end{array}$ & No association & \multirow{2}{*}{$\begin{array}{l}\mathrm{x}^{2}=2.874 \\
\mathrm{P}=0.238\end{array}$} & \multirow{2}{*}{ Non Sig. } \\
\hline Recurrent attack & $\begin{array}{c}4 \\
(15.39 \%)\end{array}$ & $\begin{array}{c}15 \\
(57.69 \%)\end{array}$ & $\begin{array}{c}7 \\
(26.92 \%)\end{array}$ & & \\
\hline
\end{tabular}

Table (4): Association between CYP2C9 (430 C > T) gene mutation and frequency of recurrence.

\begin{tabular}{|c|c|c|c|c|c|}
\hline \multicolumn{6}{|c|}{$\overline{C \text { CYP2C9 (430 C>T) }}$} \\
\hline Parameters & Wild type & Heterozygous & Homozygous & Test of sig. and $P$ value & Sig. \\
\hline $\begin{array}{l}\text { Single } \\
\text { attack }\end{array}$ & $100 \%$ & $\begin{array}{c}\text { No } \\
\text { association }\end{array}$ & No association & \multirow{2}{*}{$\begin{array}{l}\mathrm{x}^{2}=3.801 \\
\mathrm{P}=0.051\end{array}$} & \multirow{2}{*}{ Non Sig. } \\
\hline Recurrent attack & $\begin{array}{c}20 \\
(77 \%)\end{array}$ & $\begin{array}{c}6 \\
(23 \%)\end{array}$ & No association & & \\
\hline
\end{tabular}


Table (5): Association between VKORC1 (1639 G>A) gene mutation, CYP2C9 (430 C>T) gene mutation and response to Marevan dose at $\geq 5 \mathrm{mg}$.

\begin{tabular}{|c|c|c|c|c|c|}
\hline \multicolumn{6}{|c|}{ "VKORC1 (1639 G>A) } \\
\hline Parameters & Wild type & Heterozygous & Homozygous & $\begin{array}{l}\text { Test of sig. } \\
\text { and P value }\end{array}$ & Sig. \\
\hline $\begin{array}{c}\text { Non } \\
\text { responders }\end{array}$ & $\begin{array}{c}6 \\
(46.15 \%)\end{array}$ & $\begin{array}{c}6 \\
(46.15 \%)\end{array}$ & $\begin{array}{c}1 \\
(7.7 \%)\end{array}$ & \multirow{2}{*}{$\begin{array}{c}x^{2}=4.602 \\
P=0.1\end{array}$} & \multirow{2}{*}{ Non Sig. } \\
\hline Responders & $4(14.8 \%)$ & $\begin{array}{c}20 \\
(74 \%)\end{array}$ & $\begin{array}{c}3 \\
(11.11 \%)\end{array}$ & & \\
\hline \multicolumn{6}{|c|}{ CYP2C9 $(430 \mathrm{C}>\mathrm{T})$} \\
\hline $\begin{array}{c}\text { Non } \\
\text { responders }\end{array}$ & $10(76.92 \%)$ & $3(23.08 \%)$ & No association & \multirow{2}{*}{$\begin{array}{l}\mathrm{X}^{2}=0.985 \\
\mathrm{P}=0.321\end{array}$} & \multirow{2}{*}{ Non Sig. } \\
\hline Responders & $24(88.89 \%)$ & $3(11.11 \%)$ & No association & & \\
\hline
\end{tabular}

Table (6): Association between CYP2C9 (430 C>T) gene mutation, VKORC1 (1639 G>A) gene mutation and response to Marevan during 3 months of therapy:

\begin{tabular}{|c|c|c|c|c|c|}
\hline \multicolumn{6}{|c|}{ VKORC1 (1639 G>A) } \\
\hline Parameters & Wild type & Heterozygous & Homozygous & $\begin{array}{l}\text { Test of sig. } \\
\text { and } P \text { value }\end{array}$ & Sig. \\
\hline Non responders & $7(35 \%)$ & $12(60 \%)$ & $1(5 \%)$ & \multirow{2}{*}{$\begin{array}{l}\mathrm{X}^{2}=2.754 \\
\mathrm{P}=0.252\end{array}$} & \multirow{2}{*}{ Non Sig. } \\
\hline Responders & $3(15 \%)$ & $14(70 \%)$ & $3(15 \%)$ & & \\
\hline \multicolumn{6}{|c|}{ CYP2C9 (430 C>T) } \\
\hline Non responders & $18(90 \%)$ & $2(10 \%)$ & No association & \multirow{2}{*}{$\begin{array}{l}x^{2}=0.784 \\
P=0.376\end{array}$} & \multirow{2}{*}{ Non Sig. } \\
\hline Responders & $16(80 \%)$ & $4(20 \%)$ & No association & & \\
\hline
\end{tabular}

Table (7): Association between genotypes and the following parameters: WBC count, Hb, Platelet count, INR at 2-3 mg Marevan dose and INR at $>5 \mathrm{mg}$ Marevan dose.

\begin{tabular}{||l|c|c|c|c|c|c||}
\hline & \multicolumn{2}{|c|}{ VKORC1 (1639 G>A) } & \multicolumn{3}{c|}{ CYP2C9 (430C>T) } \\
\hline \hline WBC & Association & $\mathrm{p}$-value & Significance & Association & p-value & Significance \\
\hline Hb & 74.231 & 0.102 & Non-sig. & 28.235 & 0.558 & Non-sig. \\
\hline Platelet & 62.923 & 0.190 & Non-sig. & 28.889 & 0.366 & Non-sig. \\
\hline $\begin{array}{l}\text { INR at 2-3mg } \\
\text { Marevan }\end{array}$ & 67.462 & 0.496 & Non-sig. & 36.078 & 0.372 & Non-sig. \\
\hline $\begin{array}{l}\text { INR at >5mg } \\
\text { Marevan }\end{array}$ & 60.995 & 0.427 & Non-sig. & 29.542 & 0.078 & Non-sig. \\
\hline
\end{tabular}


Regarding the distribution of VKORC1(1639 $\mathrm{G}>\mathrm{A})$ genotypes, we found that $65 \%$ of patients showed heterozygous form of the gene, $25 \%$ were homozygous and $10 \%$ were wild type. We found that all studied patients showed the wild type of the gene. Whereas, none of the patients showed homozygous CYP2C9 $(430 \quad \mathrm{C}>\mathrm{T})$ genotype. As for the distribution of patients with CYP2C9 (430 $\mathrm{C}>\mathrm{T})$ genotype, there were $6 \quad(15 \%)$ heterozygous patients and $34(85 \%)$ patients showed the wild type of the gene. Interestingly all patients carrying this mutation were as well mutant for VKORC1 (1639 G>A) gene. Phenotypically, all our patients were resistant to vitamin $\mathrm{k}$ antagonist anticoagulation at a dose of 2-3 mg. The distribution of patients with CYP2C9 alleles according to gender, there were $5(83.333 \%)$ females with heterozygous CYP2C9 (430 C>T), 19 (55.88\%) females showing wild type of the gene and $15(44.1 \%)$ were males showing the wild type and $1(16.667 \%)$ male showing heterozygous type of the same gene. Whereas, CYP2C9 (1075 $\mathrm{A}>\mathrm{C})$ allele patients had the distribution of 24 $(60 \%)$ females and $16(40 \%)$ were male patients. We found significant statistical relation between CYP2C9 gene mutation and the age and insignificant with gender. There is insignificant relation between CYP2C9 genotypes and the following parameters: response to vitamin $\mathrm{K}$ antagonist oral anticoagulation at a dose of $\geq 5 \mathrm{mg}$, response during duration of therapy of $\leq 3$ months and frequency of occurrence of DVT. All the studied patients were non-responders at dose of vitamin $\mathrm{k}$ antagonist oral anticoagulation, of 2-3 mg. 36/40 (90\%) patients were mutant regarding VKORC1 gene [10 $(25 \%)$ of them were homozygous and 26 (65\%) were heterozygous]. Increasing the dose of vitamin $\mathrm{k}$ antagonist oral anticoagulation to $\geq 5 \mathrm{mg}$, $27 / 40(67.5 \%)$ of the patients, achieved appropriate response; of them $4(14.8 \%)$ were homozygous to VKORC1 gene, 20 (77\%) heterozygous and $3(11.5 \%)$ were wild type. The remaining 13/40 (35\%) were persistently resistant to dose of vitamin $\mathrm{k}$ antagonist oral anticoagulation of $\geq 5 \mathrm{mg}$; of which $6(46.1 \%)$ were homozygous, $6 \quad(46.1 \%)$ were heterozygous and only one $(7.8 \%)$ patient was wild type for the VKORC1 gene. Some patients were responders at lower doses (2-
$3 \mathrm{mg}$ ) of vitamin $\mathrm{k}$ antagonist oral anticoagulation while other patients required higher doses ( $\geq 5 \mathrm{mg}$ ) to reach their target INR. Regarding the distribution of CYP2C9 (1075 $\mathrm{A}>\mathrm{C}$ ), all studied patients showed the wild type of the gene. As for the distribution of CYP2C9 $\quad(430 \quad \mathrm{C}>\mathrm{T}), \quad 6 / 40 \quad(15 \%)$ were heterozygous. As for non-responder patients at Marevan dose of $\geq 5 \mathrm{mg}$, they were $13(32.5 \%)$ patients. Their distribution according to CYP2C9 (430 C>T) gene mutation revealed that $3(23.1 \%)$ were heterozygous and 10 (76.9\%) showed the wild type of the gene. Regarding their distribution according to VKORC1 (1639 G>A), 6 (46.2\%) were heterozygous, $6(46.2 \%)$ were homozygous and $1(7.6 \%)$ showed the wild type of the gene. Regarding Patients with single attack of DVT, they were $16(40 \%)$ where $12(75 \%)$ were females and $4(25 \%)$ were males with a male to female ratio of $1: 3$. As for patients with recurrent attacks of DVT, they were 24 $(60 \%)$ in number where $13(54.2 \%)$ were females and $11(45.8 \%)$ were males with a male to female ratio of $1: 1.2$. The correlation between VKORC1 gene mutation and frequency of occurrence of DVT in the present study, it was found to be statistically insignificant. The patients with combined VKORC1 and CYP2C9 gene mutation were all females with history of recurrence of DVT. Their number was 6 , the genotypes of 5 of them was combined heterozygous mutation for both VKORC1 and CYP2C9 (430 C>T) and only one female patient showed homozygous mutation for VKORC1 and heterozygous gene mutation for CYP2C9 (430 C>T). All these patients showed wild type of the gene CYP2C9 (1075 A>C). There is significant relation between INR at $>5$ mg Marevan dose and genotypes of VKORC1 (1639 G>A) and CYP2C9 (430C>T). There was no data available in other studies, regarding the relation between VKORC1 $(1639 \mathrm{G}>\mathrm{A})$ and CYP2C9 $\quad(430 \mathrm{C}>\mathrm{T})$ genotypes and INR at high dose of Marevan more than $5 \mathrm{mg}$.

\section{DISCUSSION}

Warfarin is an oral anticoagulant widely used in the treatment and prophylaxis of arterial and venous thromboembolic diseases. The treatment efficacy and safe use of warfarin is 
followed with prothrombin time expressed INR. INR values exceeding the therapeutic levels lead to increase in hemorrhage risk, while INR values below the therapeutic levels cause an increase in thromboembolic events ${ }^{(11,}$ 12).

The differences among individuals regarding daily effective maintenance warfarin dose caused difficulty in establishing initial dose and follow-up of therapy. Warfarin dose requirement is affected by many factors such as gender, age, diet, race, concomitant medication, and genetic factors. In recent years, the influence of genetic factors on warfarin dose requirements had come under investigation ${ }^{(13)}$.

Polymorphisms in the genes encoding for vitamin $\mathrm{K}$ epoxide reductase complex 1 (VKORC1) and cytochrome P450 2C9 (CYP2C9) are known to contribute to variations in the sensitivity to warfarin. Multiple in vivo studies also showed that several mutant CYP2C9 genotypes were associated with significant reduction in metabolism and daily dose requirements of selected CYP2C9 substrate ${ }^{(14)}$. Nucleotide variations in VKORC1 are a common cause of pharmacodynamic warfarin resistance ${ }^{(15)}$.

The aim of present study was to assess the allelic frequencies of CYP2C9 and VKORC1 genetic polymorphisms upon oral anticoagulation requirements. Inclusion criteria were: adult patients with history of DVT, regular continuous intake of oral anticoagulants (vitamin $\mathrm{k}$ antagonists), records of all previous INR results since the start of treatment (for a duration of therapy of at least 3 months) and presence of inappropriate INR results in patient's follow up records in response to dose of oral anticoagulants (vitamin $\mathrm{k}$ antagonists).

In the present study, regarding the distribution of VKORC1(1639 G>A) genotypes, we found that $65 \%$ of patients showed heterozygous form of the gene, $25 \%$ were homozygous and $10 \%$ were wild type. In contrary Herman et al. (16) reported that VKORC1 genotypes, heterozygous VKORC1 genotype was found in $34.3 \%$ of patients, homozygous was found in $2.1 \%$ patients and wild type was found in $63.6 \% \%$ patients. Moreover, D'Andrea et al. ${ }^{(17)}$ reported that the distribution of patients with VKORC1 $(1639$ G>A) genotype was $11 \quad(45.8 \%)$ patients were heterozygous and 13 (54.2\%) patients showed the wild type (1639 AA) of the gene. ${ }^{(18)}$ reported that there were $(35.7 \%)$ heterozygous, (29.7\%) homozygous and $(32.5 \%)$ were wild type, which is different from the previous studies.

These variations in results were attributed to different selection criteria. In the present study, selection of patients was based upon resistance to vitamin $\mathrm{K}$ antagonist oral anticoagulation at a dose of 2-3 $\mathrm{mg}$, whereas in other studies the selection of patients on oral anticoagulation was random. As well, these differences may be attributed to ethnic differences among patients upon whom the study was carried out. It is evident that ethnic differences in allelic frequencies of VKORC11639G $>$ A SNP and CYP2C $9 * 2$ and $* 3$ do exist. These allelic differences could explain in part the ethnic variability of warfarin dose requirements. Since warfarin dose requirements vary significantly by race, with higher mean maintenance doses in AfricanAmericans and lower mean doses in Asians compared with doses in Caucasians ${ }^{(4,19)}$.

CYP2C9 is an important cytochrome P450 enzyme with a major role in the oxidation of both xenobiotic and endogenous compounds. CYP2C9 makes up about $18 \%$ of the cytochrome $\mathrm{P} 450$ protein in liver microsomes. Some 100 therapeutic drugs are metabolized by CYP2C9, including drugs with a narrow therapeutic index such as warfarin and phenytoin and other routinely prescribed drugs such as acenocoumarol, tolbutamide, losartan, glipizide, and some nonsteroidal anti-inflammatory drugs. By contrast, the known extrahepatic CYP2C9 often metabolizes important endogenous compound such as arachidonic acid, 5hydroxytryptamine and linoleic acids ${ }^{(20)}$.

We studied CYP2C9 (430 C>T) and $(1075 \mathrm{~A}>\mathrm{C})$, we found that all studied patients showed the wild type of the gene. Whereas, none of the patients showed homozygous CYP2C9 (430 C>T) genotype. As for the distribution of patients with CYP2C9 (430 $\mathrm{C}>\mathrm{T})$ genotype, they were $6 \quad(15 \%)$ heterozygous patients and $34(85 \%)$ patients showed the wild type of the gene. Interestingly all patients carrying this mutation, were as well mutant for VKORC1 (1639 G>A) gene and phenotypically all our patients were resistant to 
vitamin $\mathrm{k}$ antagonist anticoagulation at a dose of 2-3 mg.

In the present study, we found the distribution of patients with CYP2C9 alleles according to gender, they were $5(83.333 \%)$ females with heterozygous CYP2C9 (430 C>T), 19 (55.88\%) females showing wild type of the gene and 15 (44.1\%) were males showing the wild type and $1(16.667 \%)$ male showing heterozygous type of the same gene. Whereas, CYP2C9 (1075 A>C) allele patients had the distribution of $24(60 \%)$ females and $16(40 \%)$ were male patients.

It is evident that ethnic differences in allelic frequencies of VKORC1-1639G>A SNP and $C Y P 2 C 9 * 2$ and $* 3$ do exist. These allelic differences could explain in part the ethnic variability of warfarin dose requirements. Since warfarin dose requirements vary significantly by race, with higher mean maintenance doses in African- Americans and lower mean doses in Asians compared with doses in Caucasians ${ }^{(4,21)}$.

This difference in warfarin dose requirement could be attributed to the fact that CYP2C $9 * 1$ metabolizes warfarin normally, $C Y P 2 C 9 * 2$ reduces warfarin metabolism by $66 \%$, and $C Y P 2 C 9 * 3$ reduces warfarin metabolism by $95 \%$. Consequently, warfarin given to patients with $* 2$ or $* 3$ variants were metabolized less efficiently, the drug will remain in circulation longer, so lower warfarin doses was needed to achieve anticoagulation (24).

In the present study, we found significant statistical relation between CYP2C9 gene mutation and the age and insignificant with gender. On alignment of these observations, we found insignificant relation between CYP2C9 genotypes and the following parameters: response to vitamin $\mathrm{K}$ antagonist oral anticoagulation at a dose of $\geq 5 \mathrm{mg}$, response during duration of therapy of $\leq 3$ months and frequency of occurrence of DVT. Zhang et al., ${ }^{(22)}$ revealed that the results of the association of each of the CYP2C9 genotypes with the warfarin maintenance dose was significantly related to the genotype.

In the present study, significant association was found between VKORC1 genotypes and age. This is the same as Retti et al. ${ }^{(23)}$ who stated that there was significant association between age and VKORC1.

As mentioned before in the inclusion criteria, all the studied patients were nonresponders at dose of vitamin $\mathrm{k}$ antagonist oral anticoagulation, of 2-3 mg. 36/40 (90\%) patients were mutant regarding VKORC1 gene; $10(25 \%)$ of them were homozygous and $26(65 \%)$ were heterozygous. Increasing the dose of vitamin $\mathrm{k}$ antagonist oral anticoagulation to $\geq 5 \mathrm{mg}, 27 / 40(67.5 \%)$ of the patients, achieved appropriate response; 4 $(14.8 \%)$ of them were homozygous to VKORC1 gene, $20(77 \%)$ heterozygous and 3 $(11.5 \%)$ were wild type.

The remaining 13/40 (35\%) were persistently resistant to dose of vitamin $\mathrm{k}$ antagonist oral anticoagulation of $\geq 5 \mathrm{mg}$; of which $6(46.1 \%)$ were homozygous, $6(46.1 \%)$ were heterozygous and only one (7.8\%) patient was wild type for the VKORC1 gene.

As an explanation, some patients were responders at lower doses (2-3 $\mathrm{mg}$ ) of vitamin $\mathrm{k}$ antagonist oral anticoagulation while other patients required higher doses $(\geq 5 \mathrm{mg})$ to reach their target INR.

Regarding the distribution of CYP2C9 (1075 A>C), all studied patients showed the wild type of the gene. As for the distribution of CYP2C9 $\quad(430 \quad \mathrm{C}>\mathrm{T}), \quad 6 / 40 \quad(15 \%)$ were heterozygous.

As for non-responder patients at Marevan dose of $\geq 5 \mathrm{mg}$, they were 13 (32.5\%) patients. Their distribution according to CYP2C9 (430 C>T) gene mutation revealed that $3(23.1 \%)$ were heterozygous and 10 (76.9\%) showed the wild type of the gene. Regarding their distribution according to VKORC1 (1639 G>A), 6 (46.2\%) were heterozygous, $6(46.2 \%)$ were homozygous and $1(7.6 \%)$ showed the wild type of the gene.

In the current study, Regarding Patients with single attack of DVT were 16 $(40 \%)$. They were $12(75 \%)$ females and 4 (25\%) males with a male to female ratio of $1: 3$. As for patients with recurrent attacks of DVT, they were $24(60 \%)$ in number, 13 $(54.2 \%)$ were females and $11(45.8 \%)$ were males; with a male to female ratio of 1:1.2.

The correlation between VKORC1 gene mutation and frequency of occurrence of 
DVT in the present study was found to be statistically insignificant.

The patients with combined VKORC1 and $\mathrm{CYP} 2 \mathrm{C} 9$ gene mutation were all females with history of recurrence of DVT. Their number was 6 , the genotypes of 5 of them was combined heterozygous mutation for both VKORC1 and CYP2C9 (430 C>T) and only one female patient showed homozygous mutation for VKORC1 and heterozygous gene mutation for CYP2C9 (430 $\mathrm{C}>\mathrm{T})$. All these patients showed wild type of the gene CYP2C9 (1075 A>C).

In the present study, there was significant relation between INR at $>5 \mathrm{mg}$ marevan dose and genotypes of VKORC1 (1639 G>A) and CYP2C9 (430C>T). There was no data available in other studies, regarding the relation between VKORC1 $(1639 \mathrm{G}>\mathrm{A})$ and CYP2C9 $(430 \mathrm{C}>\mathrm{T})$ genotypes and INR at high dose of marevan more than $5 \mathrm{mg}$.

\section{Conclusion:}

Detection of genetic polymorphisms in CYP2C9 and VKORC1 genes prior to onset of warfarin therapy, greatly influences response to warfarin and shortens the time required to reach target INR, and hence reduces the risk of recurrence of deep venous thrombosis.

\section{References:}

1. Ansell J, Hirsh J, Poller L et al. (2005): The pharmacology and management of the vitamin K antagonists: The Seventh ACCP Conference on Antithrombotic and Thrombolytic Therapy. Chest, 127:415.

2. John R, Forum K, Kenneth $\mathrm{L}$ et al. (2008): Low thromboembolic risk for patients with the Heartmate II left ventricular assist device. J. Thorac. Cardiovasc. Surg., 136: 1318-23.

3. Margaret C, Alan SG, Jonathan LH et al. (2006): Antithrombotic Therapy in Atrial Fibrillation: American College of Chest Physicians Evidence-Based Clinical Practice Guidelines. Chest, 133: 546-592.

4. Cavallari LH, Jaekyu S, Minoli AP et al. (2011): Role of Pharmacogenomics in the Management of Traditional and Novel Oral Anticoagulants. Pharmacotherapy, doi:10.1592/phco.31.12.1192.

5. Parameshwar SR and Dattatreya $P$ V (2016): Genetic determinants of response and adverse effects following vitamin $\mathrm{K}$ antagonist oral anticoagulants. Int. J. Res. Med. Sci., 6: 2120-2124.

6. Ralph R and John MW (2009): Molecular Diagnostic. Molecular Biology and Biotechnology, 3: 60 -68.

7. Vatandoost $\mathbf{J}$ and Seyyedeh FP (2016): The Effects of Influencing Factors on carboxylation and Expression of Recombinant Vitamin K Dependent Coagulation Factors. VKORC1. Thrombosis and Haemostasis, 6 (10): 1663-1670.

8. Fung E, Nikolaos A P, Steven M B et al. (2012): Effect of Genetic Variants, Especially CYP2C9 and VKORC1 on the Pharmacology of Warfarin. Semin. Thromb. Hemost., 38(8): 893-904.

9. Tamura T, Nobuyuki $K$ and Nobuyuki H (2014): A PCR method for VKORC1 G-1639A and CYP2C9 A1075C genotyping useful to warfarin therapy among Japanese. Springer Plus, 3: 499.

10. Schwarz U, Marylyn DR, Yuki B et al. (2008): Genetic Determinants of Response to Warfarin during Initial /Anticoagulation. N. Engl. J. Med., 358: 999-1008.

11. Ozer N, Cam N, Tangurek BS et al. (2010): The impact of CYP2C9 and VKORC1 genetic polymorphism and patient characteristics upon warfarin dose requirements in an adult Turkish population. Heart and vessels, 25 (2): 155-162.

12. Kadian-D, van der Zee $S$, Scott $S$ et al. (2013): Warfarin pharmacogenetics: A controlled dose-response study in healthy subjects. Vascular Medicine, 18 (5): 290-297.

13. Levenson D (2014): New Data on Pharmacogenetic Anticoagulant Dosing. Journal of Infectious Diseases, 209: 325- 333.

14. Garcia D, Regan S, Crowther et al. (2006): Warfarin maintenance dosing patterns in clinical practice: implications for safer anticoagulation in the elderly population. Chest, 127 (6): 2049-2056.

15. Harrington D, Gorska R, Wheeler $\mathrm{R}$ et al. (2008): Pharmacodynamic resistance to warfarin is associated with nucleotide substitutions in in VKORC1. J. Thromb. Haemost., 6(10):1663-70. 
16. Herman D, Locatelli I, Grabnar I et al. (2005): Influence of CYP2C9 polymorphisms, demographic factors and concomitant drug therapy on warfarin metabolism and maintenance dose. Pharmacogenomics J., 5: 193-202.

17. D'Andrea G, D'Ambrosio RL, Di Perna $P$ et al. (2005): A polymorphism in the VKORC1 gene is associated with an interindividual variability in the doseanticoagulant effect of warfarin. Blood, 105: 645-64.

18. Budnitz DS, Shehab N, Kegler SR et al. (2007): Medication use leading to emergency department visits for adverse drug events in older adults. Ann. Intern. Med., 147: 755-765.

19. Bazan N S, Sabry N A, Rizk A et al. (2014): Factors affecting warfarin dose requirements and quality of anticoagulation in adult Egyptian patients: role of gene polymorphism. Irish Journal of Medical Science, 183 (2): 161-172.
20. Zhou S F, Zhou WZ and Huang $M$ (2009): Polymorphisms of human cytochrome P450 2C9 and the functional relevance. J. Pharmacol. Exp. Ther., 311 (1): $34-43$.

21. Rieder M J, Reiner AP, Gage B F et al. (2005): Effect of VKORC1 haplotypes on transcriptional regulation and warfarin dose. New England Journal of Medicine, 352(22): 2285-2293.

22. Zhang J, Tian $\mathbf{L}$, Huang $\mathrm{J}$ et al. (2017): Cytochrome P450 2C9 gene polymorphism and warfarin maintenance dosage in pediatric patients: A systematic review and meta-analysis. Cardiovascular Therapeutics, 35: 26-32.

23. Rettie AE, Wienkers LC, Gonzalez FJ et al. (2005): Effect of VKORC1 haplotypes on transcriptional regulation and warfarin dose. New England Journal of Medicine, 352(22), 2285-2293. 